RESEARCH REPORT

\title{
Environmental perceptions and walking in English adults
}

\section{Charles Foster, Melvyn Hillsdon, Margaret Thorogood}

J Epidemiol Community Health 2004;58:924-928. doi: 10.1136/jech.2003.014068

\begin{abstract}
Study objective: To examine the relation between adults' perceptions of the social and physical environment and their self reported walking behaviour.

Design: Cross sectional survey.

Setting: England.

Participants: A national sample of 4265 adults aged 16-74 years.

Main outcome measures: Self reported walking behaviour was categorised into two dichotomous variables: (a) any reported walking in past four weeks, (b) reported walking $\geqslant 150$ minutes per week in the past four weeks. Perceptions of the social environment covered safety of walking alone and social support for walking. Perceptions of the physical environment covered attractiveness of local area for walking, access to shops, leisure centres, parks, cycle paths, and traffic density. Main results: In women, perceived safety of walking during the day $(\mathrm{OR}=0.53 ; 95 \% \mathrm{Cl}$ : 0.31 to 0.88$)$, and no shop within walking distance $(O R=0.72 ; 95 \% \mathrm{Cl}: 0.52$ to 0.99$)$ were associated with any reported walking occasions. Perceptions of the environment were not related to women walking $\geqslant 150 \mathrm{~min} /$ week. In men, having a park within walking distance was associated with walking $\geqslant 150 \mathrm{~min} /$ week $(O R=2.22$; $95 \% \mathrm{Cl}: 1.18$ to 4.35$)$. No other significant associations were found.

Conclusions: Women seem to be more concerned about walking for utility and in safety. Men are more likely to walk $\geqslant 150 \mathrm{~min} /$ week if they have access to a local park but their walking is not influenced by concerns about safety. Future research should focus on the relation between objective measures rather

than perceptions of the environment and physical activity.
\end{abstract}

See end of article for authors' affiliations

26 January 2004

.....................

Mr C Foster, University of

Oxford, Institute of Health

Sciences, Oxford OX3 7LF,

UK; charlie.foster@dphpc.

ox.ac.uk

O bservational studies show that people who undertake moderate to high levels of physical activity, including walking, have a lower risk of chronic diseases, such as coronary heart disease, hypertension, and diabetes. ${ }^{1-4}$ Although there is some debate about the precise amount of physical activity needed for protection against cardiovascular mortality, people who are physically active typically experience a $30 \%-50 \%$ reduction in relative risk of coronary heart disease compared with people who are sedentary. ${ }^{56}$

A number of international and national health bodies, including the UK's Department of Health, have produced common recommendations for physical activity advising that adults should undertake at least 30 minutes of moderate intensity physical activity (an activity with an energy expenditure of $\geqslant 5 \mathrm{kcal} / \mathrm{min}$ but $\leqslant 7.5 \mathrm{kcal} / \mathrm{min}$ ) on at least five days of the week. ${ }^{7-9}$ However, only $37 \%$ of men and $25 \%$ of women in England are active at this level. ${ }^{10}$ UK adults report only low levels of walking."

In response to low levels of adult physical activity the Health Education Authority was commissioned by the Department of Health to run a three year health promotion campaign. The Active for Life campaign aimed to increase public knowledge of the moderate intensity physical activity message and to increase adults' levels of moderate intensity physical activity, especially walking. It was evaluated by three annual surveys of a representative sample of adults. The authors obtained permission from the Health Development Agency (formally the Health Education Authority) to analyse these data.

In this paper we report on the relation between perceptions of the physical and social environment and two measures of walking behaviour, as reported in the second annual survey (wave 2) of the three surveys of the sample cohort. Our a priori hypothesis was that associations between perceptions of the social and physical environments would be different for men and women for different patterns of walking.

\section{METHODS \\ Sample}

The evaluation methods of the Active for Life campaign have been reported previously. ${ }^{11}$ Briefly, a nationally representative cohort of adults, aged 16-74, was recruited and followed up over three years from 1995 to 1997. The participants were selected using the small users postcode address file (PAF) for England. A multi-stage cluster random probability design was used to identify addresses. ${ }^{12}$ At each address one eligible respondent was randomly selected from one household. At baseline, in 1995, trained interviewers from a social marketing company interviewed participants at home. The 30 minute interview collected data on reported physical activity, physical health, knowledge of and attitudes towards physical activity, and perceptions of barriers to physical activity, plus sociodemographic information. In wave 2 (1996) a series of questions were added to the interview asking about participants' perceptions of the physical and social environment. The Health Education Authority approved the original study. The variables used in this study all came from wave 2.

\section{Outcome measure}

Physical activity was assessed by asking participants about the frequency, duration, intensity, and type of physical activity they had performed in the previous four weeks. The types of physical activities were occupational, walking, heavy housework/DIY, gardening, and sport/recreation. Walking included any occasion of walking for at least 15 minutes, whatever the purpose of the walk.

\section{Perceived environment}

Nine questions were asked about the participant's perceptions of their physical and social environment. A Likert scale was used to categorise some responses, while others were simple yes/no responses. ${ }^{13}$ The statements related to the social 
Table 1 Characteristics of 4157 participants in the 1996 Active for Life survey (wave 2), demographics, self reported walking, and perceptions of the environment by gender

\begin{tabular}{|c|c|c|c|c|}
\hline \multirow[b]{2}{*}{ Number of subjects } & \multirow{2}{*}{$\frac{\text { Men }}{1784}$} & \multirow{2}{*}{$\begin{array}{l}\text { Women } \\
2373\end{array}$} & \multirow{2}{*}{$\begin{array}{l}\text { All } \\
4157\end{array}$} & \multirow[b]{2}{*}{$\mathbf{p}$} \\
\hline & & & & \\
\hline \multicolumn{5}{|l|}{ Demographics } \\
\hline Age group (\%) & & & & 0.39 \\
\hline $16-24$ & 7.2 & 6.9 & 7.0 & \\
\hline $25-34$ & 16.9 & 19.2 & 18.2 & \\
\hline $35-44$ & 19.3 & 20.1 & 19.8 & \\
\hline $45-54$ & 20.1 & 18.5 & 19.1 & \\
\hline $55-64$ & 16.5 & 16.3 & 16.4 & \\
\hline $65-74$ & 20.1 & 19.0 & 19.5 & \\
\hline Social status (\%) & & & & $<0.01$ \\
\hline$A B$ & 23.4 & 12.8 & 17.4 & \\
\hline $\mathrm{Cl}$ & 29.1 & 35.4 & 32.7 & \\
\hline $\mathrm{C} 2$ & 22.6 & 13.4 & 17.3 & \\
\hline $\mathrm{DE}$ & 24.8 & 38.4 & 32.6 & \\
\hline Educational qualifications (\%) & & & & $<0.01$ \\
\hline A levels or higher & 39.4 & 28.3 & 33.1 & \\
\hline Any qualifications & 33.3 & 33.9 & 33.7 & \\
\hline No qualifications & 27.2 & 37.8 & 33.3 & \\
\hline Self reported health limitation (\%) & & & & $<0.01$ \\
\hline Yes & 36.2 & 41.2 & 39.0 & \\
\hline Car use (\%) & & & & $<0.01$ \\
\hline Yes & 80.7 & 69.6 & 74.4 & \\
\hline Home ownership (\%) & & & & 0.07 \\
\hline Owned/being bought & 78.2 & 75.5 & 76.7 & \\
\hline Walking & & & & \\
\hline Walking for at least $15 \mathrm{~min} /$ week (\%) & & & & 0.43 \\
\hline$\leqslant 15 \mathrm{~min} /$ week & 10.5 & 11.3 & 10.9 & \\
\hline$\geqslant 15 \mathrm{~min} /$ week & 89.5 & 88.7 & 89.1 & \\
\hline Walking for at least $150 \mathrm{~min} /$ week (\%) & & & & 0.32 \\
\hline$\leqslant 150 \mathrm{~min} /$ week $(\%)$ & 89.1 & 88.1 & 88.5 & \\
\hline$\geqslant 150 \mathrm{mins} /$ week & 10.9 & 11.9 & 11.5 & \\
\hline Perceptions of environment & & & & \\
\hline Safe to walk in the day (\%) & & & & $<0.01$ \\
\hline High safety & 97.0 & 93.1 & 94.8 & \\
\hline Low safety & 3.0 & 6.9 & 5.2 & \\
\hline Safe to walk at night (\%) & & & & $<0.01$ \\
\hline High safety & 68.2 & 29.5 & 46.1 & \\
\hline Low safety & 31.8 & 70.5 & 53.9 & \\
\hline Park/open space convenience (\%) & & & & 0.52 \\
\hline High convenience & 89.3 & 88.6 & 88.9 & \\
\hline Low convenience & 10.7 & 11.4 & 11.1 & \\
\hline Local shops convenience (\%) & & & & 0.33 \\
\hline High convenience & 69.3 & 70.8 & 70.1 & \\
\hline Low convenience & 30.7 & 29.2 & 29.9 & \\
\hline Neighbourhood aesthetics (\%) & & & & $<0.01$ \\
\hline High aesthetics & 60.7 & 74.4 & 68.9 & \\
\hline Low aesthetics & 39.3 & 25.6 & 31.1 & \\
\hline Neighbourhood traffic (\%) & & & & $<0.01$ \\
\hline High traffic levels & 93.5 & 88.8 & 90.8 & \\
\hline Low traffic levels & 6.5 & 11.2 & 9.2 & \\
\hline Access to leisure centre (\%) & & & & 0.04 \\
\hline High access & 90.1 & 88.1 & 88.9 & \\
\hline Low access & 9.9 & 11.9 & 11.1 & \\
\hline Company (\%) & & & & 0.19 \\
\hline Has company & 36.6 & 34.6 & 35.5 & \\
\hline No company & 63.4 & 65.4 & 64.5 & \\
\hline No company (\%) & & & & 0.51 \\
\hline Not prefer company & 30.9 & 31.9 & 31.5 & \\
\hline Prefers company & 69.1 & 68.1 & 68.5 & \\
\hline
\end{tabular}

or physical aspects of the environment. The assessment procedure and statements are given in the appendix.

\section{Demographic details}

The sociodemographic data collected included age, gender, social status, educational qualifications, self reported health status, and car ownership. Health status was evaluated by a question asking whether participants had any illness, disability, or health condition that limited their physical activity. Car use was assessed by asking participants whether they had access to a car or van.

\section{Data analysis}

We created two categorical variables for self reported walking: walking for at least 15 minutes per week in the past four weeks and walking $\geqslant 150$ minutes per week in the past four weeks. We felt that it was inappropriate to combine perceptions of the environment into summary variables as two types of measure were involved (responses to statements using Likert scales or yes/no responses). However, we collapsed responses to the Likert items into agree ( 1 or 2 ) or disagree ( 4 or 5 ) categories. Responses in the neither agree or disagree category were excluded from the analysis. Age 
Table 2 Description of the 4157 participants in the 1996 Active for Life survey (wave 2) perceptions of the environment by gender and self reported levels of walking

\begin{tabular}{|c|c|c|c|c|c|c|c|c|c|c|}
\hline \multirow[b]{3}{*}{ Perceptions of environment } & \multicolumn{5}{|c|}{ Women } & \multicolumn{5}{|l|}{ Men } \\
\hline & \multicolumn{3}{|c|}{$\begin{array}{l}\text { Walking for at least } 15 \mathrm{~min} / \\
\text { week }\end{array}$} & \multicolumn{2}{|c|}{$\begin{array}{l}\text { Walking for at least } \\
150 \mathrm{~min} / \text { week }\end{array}$} & \multicolumn{3}{|c|}{$\begin{array}{l}\text { Walking for at least } 15 \mathrm{~min} / \\
\text { week }\end{array}$} & \multicolumn{2}{|c|}{$\begin{array}{l}\text { Walking for at least } \\
150 \mathrm{~min} / \text { week }\end{array}$} \\
\hline & $\mathbf{N}$ & $\begin{array}{l}\geqslant 15 \mathrm{~min} / \\
\text { week }\end{array}$ & $\mathbf{p}$ & $\begin{array}{l}\geqslant 150 \mathrm{~min} / \\
\text { week }\end{array}$ & $\mathbf{p}$ & $\mathbf{N}$ & $\begin{array}{l}\geqslant 15 \mathrm{~min} / \\
\text { week }\end{array}$ & $\mathbf{p}$ & $\begin{array}{l}\geqslant 150 \mathrm{~min} / \\
\text { week }\end{array}$ & $\mathbf{p}$ \\
\hline Safe to walk in the day & 2305 & & & & & 1757 & & & & \\
\hline High safety & & 89.0 & & 12.2 & & & 89.4 & & 11.0 & \\
\hline Low safety & & 84.8 & 0.11 & 7.6 & 0.08 & & 92.3 & 0.51 & 9.6 & 0.76 \\
\hline Safe to walk at night & 2064 & & & & & 1560 & & & & \\
\hline High safety & & 89.0 & & 10.9 & & & 89.0 & & 11.6 & \\
\hline Low safety & & 88.3 & 0.64 & 11.4 & 0.72 & & 89.9 & 0.59 & 10.1 & 0.39 \\
\hline Park/open space convenience & 2129 & & & & & 1590 & & & & \\
\hline High convenience & & 88.2 & & 12.3 & & & 89.3 & & 11.6 & \\
\hline Low convenience & & 91.3 & 0.15 & 9.5 & 0.21 & & 92.9 & 0.14 & 7.1 & 0.07 \\
\hline Local shops convenience & 2089 & & & & & 1568 & & & & \\
\hline High convenience & & 89.2 & & 11.6 & & & 89.0 & & 10.1 & \\
\hline Low convenience & & 86.7 & 0.10 & 11.8 & 0.92 & & 89.2 & 0.92 & 11.6 & 0.37 \\
\hline Neighbourhood aesthetics & 1981 & & & & & 1340 & & & & \\
\hline High aesthetics & & 88.7 & & 12.1 & & & 89.7 & & 10.6 & \\
\hline Low aesthetics & & 88.2 & 0.73 & 10.7 & 0.39 & & 89.2 & 0.78 & 10.4 & 0.93 \\
\hline Neighbourhood traffic & 2373 & & & & & 1784 & & & & \\
\hline High traffic levels & & 88.9 & & 13.2 & & & 91.4 & & 7.8 & \\
\hline Low traffic levels & & 87.2 & 0.39 & 11.8 & 0.49 & & 89.4 & & 4.6 & 0.26 \\
\hline Access to leisure centre & 2373 & & & & & 1784 & & 0.50 & & \\
\hline High access & & 88.9 & & 11.7 & & & 89.6 & & 10.7 & \\
\hline Low access & & 88.0 & 0.66 & 13.8 & 0.30 & & 88.7 & 0.71 & 13.0 & 0.35 \\
\hline Company & 2106 & & & & & 1651 & & & & \\
\hline Has company & & 88.9 & & 10.6 & & & 90.1 & & 11.6 & \\
\hline No company & & 88.3 & 0.70 & 12.8 & 0.14 & & 89.3 & 0.61 & 10.2 & 0.40 \\
\hline No company & 2317 & & & & & 1736 & & & & \\
\hline Not prefer company & & 88.0 & & 10.8 & & & 90.1 & & 9.5 & \\
\hline Prefers company & & 89.0 & 0.44 & 12.5 & 0.25 & & 89.4 & 0.51 & 11.6 & 0.20 \\
\hline
\end{tabular}

was grouped into six 10 year bands from 16 to 74 . Social status data were categorised using the social grade system. ${ }^{14}$ These categories range from Group A-professional occupational groups (doctors, lawyers, managers) to Group Eunskilled manual workers (general labourers). Educational qualifications were categorised into three groups, A level or higher qualifications, any qualifications, or none. Participants reporting any condition that limited their physical activity were excluded from the analysis $(n=108)$. A series of forced entry, logistic regression models were performed to examine the relation between perceptions of the social and physical environment and the two walking variables, using Stata 7.0. ${ }^{15}$ Separate models were produced for men and women and were adjusted for potential confounding factors: age, socioeconomic status (SES), education, self reported health status, and car use. These factors are known to be associated with physical activity. ${ }^{16}{ }^{17}$

\section{RESULTS}

Altogether 4268 interviews were conducted in wave 2, representing $64 \%$ of the 6711 respondents at baseline. A total of 4157 participants $(42.9 \%$ male) provided complete sets of environmental, sociodemographic, and walking data. Table 1 shows the characteristics of this group by gender. No significant differences between men and women, in rates of the two categories of walking were observed (walking for at least $15 \mathrm{~min} /$ week $\mathrm{p}=0.43 ; \leqslant 150 \mathrm{~min} /$ week $\mathrm{p}=0.32$ ). Women were more concerned than men about the safety of walking, particularly at night. More women also thought that their neighbourhood was pleasant for walking and fewer of them thought there was a lot of traffic. Overall the perceptions of the local environment for walking were positive for both genders.
For both men and women, there were no associations between any of the nine perceptions of the environment and the two walking categories in simple $2 \times 2$ tables (table 2 ).

In logistic regression models only three of the nine perceived social and physical environment variables were significantly associated with any type of walking for men or women (table 3 ). In women two variables were significantly associated with walking for at least 15 minutes per week. Women who reported feeling unsafe to walk in their neighbourhood during the day were $47 \%$ less likely to report walking for at least 15 minutes per week in past four weeks, than women who felt more safe (OR $=0.53 ; 95 \%$ CI: 0.31 to 0.88 ). Women who reported not having a shop within walking distance were $28 \%$ less likely to report walking for at least 15 minutes per week in the past four weeks $(\mathrm{OR}=0.72 ; 95 \%$ CI: 0.52 to 0.99$)$. No environmental variables were significantly associated with women walking more than 150 minutes per week. Age, SES, educational qualifications, self reported health, and car use were not significantly associated with walking for at least 15 minutes per week or walking more than 150 minutes per week for women.

In men the only variable significantly associated with walking more than $150 \mathrm{~min} /$ week was having a park/open space within walking distance $(\mathrm{OR}=2.22 ; 95 \% \mathrm{CI}$ : 1.18 to $4.35)$. No other significant associations were found.

\section{DISCUSSION}

Although both genders had positive perceptions of their physical and social environments their responses differed. Women's walking was related to concerns about safety to walk during the day, and having shops within walking distance. Women seemed to be concerned about utility and 
Table 3 Odds ratios and 95\% confidence intervals for participants in the 1996 Active for Life survey (wave 2) perceptions of the environment and the likelihood of any walking ( $\geqslant$ walking for at least $15 \mathrm{~min} /$ week the past four weeks) and frequent walking ( $\geqslant 150 \mathrm{~min} /$ week walking per week in the past four weeks) by gender

\begin{tabular}{|c|c|c|c|c|c|c|c|c|c|c|c|c|}
\hline \multirow{3}{*}{$\begin{array}{l}\text { Perceptions of } \\
\text { environment }\end{array}$} & \multicolumn{6}{|c|}{ Women } & \multicolumn{6}{|l|}{ Men } \\
\hline & \multicolumn{3}{|c|}{$\begin{array}{l}\geqslant \text { walking for at least } \\
15 \mathrm{~min} / \text { week }^{*}\end{array}$} & \multicolumn{3}{|c|}{$\geqslant 150 \mathrm{~min} /$ week walking* } & \multicolumn{3}{|c|}{$\begin{array}{l}\geqslant \text { walking for at least } 15 \mathrm{~min} / \\
\text { week }^{*}\end{array}$} & \multicolumn{3}{|c|}{$\geqslant 150 \mathrm{~min} /$ week walking* } \\
\hline & OR & $95 \% \mathrm{Cl}$ & $\mathbf{p}$ & OR & $95 \% \mathrm{Cl}$ & $p$ & OR & $95 \% \mathrm{Cl}$ & $\mathbf{p}$ & OR & $95 \% \mathrm{Cl}$ & $\mathbf{p}$ \\
\hline $\begin{array}{l}\text { Safe to walk in the day } \\
\text { Low safety }\end{array}$ & 0.53 & 0.31 to 0.88 & 0.01 & 0.58 & 0.31 to 1.11 & 0.10 & 1.71 & 0.55 to 5.30 & 0.35 & 0.73 & 0.28 to 1.92 & 0.53 \\
\hline $\begin{array}{l}\text { Safe to walk at night } \\
\text { Low safety } \\
\text { Park/open space } \\
\text { convenience }\end{array}$ & 0.92 & 0.66 to 1.40 & 0.65 & 1.04 & 0.72 to 1.51 & 0.82 & 1.47 & 0.97 to 2.22 & 0.07 & 0.86 & 0.57 to 1.30 & 0.47 \\
\hline $\begin{array}{l}\text { High convenience } \\
\text { Local shops convenience }\end{array}$ & 0.62 & 0.38 to 1.04 & 0.07 & 1.12 & 0.62 to 2.04 & 0.69 & 0.48 & 0.25 to 0.94 & 0.33 & 2.22 & 1.18 to 4.35 & 0.01 \\
\hline $\begin{array}{l}\text { Low convenience } \\
\text { Neighbourhood aesthetics }\end{array}$ & 0.72 & 0.52 to 0.99 & 0.03 & 1.00 & 0.71 to 1.42 & 0.97 & 1.01 & 0.68 to 1.50 & 0.94 & 1.68 & 1.10 to 2.57 & 0.15 \\
\hline $\begin{array}{l}\text { Low aesthetics } \\
\text { Neighbourhood traffic }\end{array}$ & 1.06 & 0.74 to 1.50 & 0.76 & 0.93 & 0.64 to 1.36 & 0.72 & 0.86 & 0.56 to 1.30 & 0.48 & 0.94 & 0.61 to 1.46 & 0.79 \\
\hline $\begin{array}{l}\text { High traffic levels } \\
\text { Access to leisure centre }\end{array}$ & 1.32 & 0.86 to 2.04 & 0.20 & 0.75 & 0.48 to 1.17 & 0.21 & 0.73 & 0.32 to 1.65 & 0.45 & 2.01 & 0.74 to 1.96 & 0.45 \\
\hline $\begin{array}{l}\text { High access } \\
\text { Company }\end{array}$ & 1.16 & 0.74 to 1.79 & 0.52 & 0.89 & 0.58 to 1.35 & 0.58 & 0.89 & 0.58 to 1.36 & 0.55 & 0.84 & 0.48 to 1.49 & 0.55 \\
\hline No company & 1.06 & 0.76 to 1.47 & 0.73 & 1.24 & 0.89 to 1.72 & 0.19 & 1.03 & 0.69 to 1.52 & 0.88 & 0.79 & 0.53 to 1.17 & 0.23 \\
\hline $\begin{array}{l}\text { No company } \\
\text { Prefers company }\end{array}$ & 1.14 & 0.83 to 1.56 & 0.41 & 1.22 & 0.89 to 1.67 & 0.22 & 1.10 & 0.70 to 1.71 & 0.67 & 1.22 & 0.81 & 1.84 \\
\hline
\end{tabular}

safety. Men's walking more than 150 minutes per week was related to access to a local park, with no expressed concerns about safety.

Separate regression models were constructed for men and women, as univariate analysis showed significant differences by gender and we hypothesised that the different aspects of the physical and social environment would influence men and women in a different way. Thus, our models allowed gender to act as a potential moderator of the perceived effect of the environment rather than as a confounding variable. ${ }^{18}$ Our study found similar associations to environment items to those highlighted in a recent review. ${ }^{19}$ However, our results showed gender differences that were not observed in previous studies where the association between walking and environmental variables were studied..$^{20-23}$ These other studies have not examined this potential effect of gender on such associations.

The cross sectional nature of the data does not allow us to make causal links between perceptions of the social and physical environment and walking behaviour. The study sample, a second year wave of a longitudinal evaluation study cohort, was a self selected sample of adults, suffering a

\section{Key points}

- Both genders reported positive perceptions of their physical and social environments.

- Women were more likely to report not walking for at least 15 minutes per week if they had concerns for their safety and did not have any local shops within their neighbourhood.

- Men were more likely to report walking more than $150 \mathrm{~min} /$ week if they had access to a local park or open space in their neighbourhood.

- Evidence of considerable differences in perceptions of the environment was found between genders for both low and high walking groups.
$36 \%$ loss to follow up from the original wave 1 random sample. Wave 2 participants were older, had higher SES, and greater access to a car but had the same activity levels. This would suggest that this group are likely to be more affluent than the general population sample in wave 1 . Therefore they may live in more desirable environments, which led them to report their local environments so positively. This selection bias may account for the weak associations seen in table 3 and the lack of association between other demographic factors and walking. The self reported measure of walking has not been assessed for validity or reliability but it was developed from other national surveys, including the Health Survey for England. ${ }^{10}$ This may have led to some misclassification of walking which is expected to be non-differential, leading to an attenuation of the true relation between perceptions of the environment and walking. As far as we are aware this survey's list of environmental statements was not based on other published work. However, the choice of statements and use of Likert and categorical responses were similar to question development found in other studies. ${ }^{19-22} 24$

Our results have implications for the promotion of moderate intensity physical activity in the UK. The New Opportunities Fund and partner bodies have contributed just over 12 million pounds to the "Walking the way to Health" Initiative. ${ }^{25}$ The project offers people the chance to participate in group walks, led by trained volunteers, and such an approach may help to deal with the fear of walking alone in

\section{Policy implications}

- Policies and interventions that improve the safety of street and public spaces, and maintain green spaces may also contribute to increasing levels of walking.

- Design of public spaces should reflect the needs of pedestrians over other modes of transport.

- Providing opportunities for walking with others in groups may tackle concerns for safety, particularly among female walkers. 
the day for women. The UK government has recognised the impact of fear for personal safety on walking in women and older people and that an unsafe environment "inhibits walking". ${ }^{26}{ }^{27}$ Encouraging adults to walk instead of using the car for short journeys may prove difficult if they have concerns for their personal safety and have few local facilities or destinations within walking distance.

Our results suggest that the physical environment, particularly convenience and perceived safety, influences walking behaviour in English adults. However, the study is based solely on self reported walking and perceptions of the environment. More objective measures of physical activity behaviour and the environment should be included in future research.

\section{ACKNOWLEDGEMENTS}

The Active for Life data were used with the permission of the Health Development Agency.

\section{Authors' affiliations}

C Foster, BHF Health Promotion Research Group, Department of Public Health, Institute of Health Sciences, University of Oxford, UK M Hillsdon, Health Promotion Research Unit, Department of Public Health and Policy, London School of Hygiene and Tropical Medicine, UK M Thorogood, Division of Health in the Community, Warwick Medical School, University of Warwick, UK

Funding: this research was funded by the British Heart Foundation. Conflicts of interest: none declared.

\section{APPENDIX}

Perceptions of safety, convenience, and aesthetics of the environment were assessed by asking participants about their responses to a list of five statements. The list was preceded with the statement, "I am going to read out some statements that people have made about their local neighbourhood. For each one please tell me how much you agree or disagree with them referring to your neighbourhood". Participants scored their answers using a Likert scale ranging from strongly agree (1), through neither agree or disagree (3), to strongly disagree (5). Perceptions of safety to walk alone during the day or at night, was assessed using two items, "It is safe to go out walking during the day on your own", and "It is safe to go out walking during the night on your own". Perceptions of the convenience of walking in the local neighbourhood was assessed using two items, "A park/open space is within walking distance", and "Shops are within walking distance". Aesthetics of walking in the neighbourhood was assessed using one item, "It is pleasant to go walking in my neighbourhood".

Participants were asked to respond to statements about their perceptions of the traffic, access to sports facilities and social support in relation to walking in their local environment, using dichotomous yes/no responses. Perceptions of local levels of traffic used "There is a lot of traffic in my neighbourhood". Access to local sports facilities was assessed using "A leisure centre is within walking distance from my home". Social support in the local neighbourhood was assessed using two items, "I have someone to walk with in my neighbourhood" and "I would prefer to walk with someone in my neighbourhood".

\section{REFERENCES}

1 Powell KE, Thompson PD, Caspersen CJ, et al. Physical activity and the incidence of coronary heart disease. Annu Rev Public Health 1987;8:253-87.

2 Berlin JA, Colditz GA. A meta-analysis of physical activity in the prevention of coronary heart disease. Am J Epidemiol 1990;132:639-46.

3 Hayashi T, Tsumura K, Suematsu C, et al. Walking to work and the risk for hypertension in men: The Osaka Health Survey. Ann Intern Med 1999;130:21-6.

4 Haapanen N, Miilunpalo S, Vuori I, et al. Association of leisure time physical activity with the risk of coronary heart disease, hypertension and diabetes in middle-aged men and women. Int J Epidemiol 1997;26:739-47.

5 Murphy M, Foster C, Sudlow C, et al. Primary prevention. Clin Evid 2002; 7:94-5

6 Yu S, Yarnell JW, Sweetnam PM, et al. What level of physical activity protects against cardiovascular death? The Caerphilly study. Heart 2003;89:502-6.

7 Pate RR, Pratt M, Blair SN, et al. Physical activity and public health: a recommendation from the Centers for Disease Control and Prevention and the American College of Sports Medicine. JAMA 1995;273:402-7.

8 World Health Organisation/International Federation of Sports Medicine Committee on physical activity for health. Exercise for health. Bull Health World Organ 1995;75:135-6.

9 Department of Health. Strategy statement on physical activity. London: Department of Health, 1996.

10 Joint Health Surveys Unit. Health survey for England, 1998. London: The Stationery Office, 2000.

11 Hillsdon M, Cavill N, Nanchahal K, et al. National level promotion of physical activity: results from England's Active for Life campaign. J Epidemiol Community Health 2001;55:755-61.

12 Office of Population Censuses and Surveys. Health survey for England, 1991. London: HMSO, 1993.

13 Likert R. A technique for the measurement of attitudes. New York: Columbia University Press, 1932

14 Marsh C. Social class and occupation. In: Burgess E, ed. Key variables in social investigation. London: RKP, 1986

15 Stata Press. Stata 7 users guide. Texas: Stata Press, 2001

16 US Department of Health and Human Services. Physical activity and health: a report of the surgeon general. Atlanta: US Department of Health and Human Services, Centers for Disease Control and Prevention, National Center for Chronic Disease Prevention and Health Promotion, 1996.

17 Sports Council, Health Education Authority. Allied Dunbar national fitness survey. London: HEA, 1992.

18 Bauman AE, Sallis JF, Dzewaltowski DA, et al. Towards a better understanding of the influences on physical activity: the role of determinants, correlates, causal variables, mediators, moderators, and confounders. Am J Prev Med 2002;23:5-14.

19 Humpel N, Owen N, Leslie E. Environmental factors associated with adults' participation in physical activity. A review. Am J Prev Med 2002;22:188-99.

20 Ball K, Bauman A, Leslie E, et al. Perceived environmental aesthetics and convenience and company are associated with walking for exercise among Australian adults. Prev Med 2001;33:434-40.

21 Booth M, Owen N, Bauman A, et al. Social-cognitive and perceived environment influences associated with physical activity in older Australians. Prev Med 2000;31:15-22

22 Carnegie MA, Bauman A, Marshall AL, et al. Perceptions of the physical environment, stage of change for physical activity, and walking among Australian adults. Res Q Exerc Sport 2002;73:146-55.

23 Hovell MF, Hofstetter CR, Sallis JF, et al. Correlates of change in walking for exercise: an exploratory analysis. Res Q Exerc Sport 1992;63:425-34.

24 Corti B, Donovan RJ, Holman CD. Factors influencing the use of physical activity facilities: results from a qualitative research. Health Promotion Journal of Australia 1997;7:16-21.

25 Reynolds V. Using the countryside as a health resource to promote physical activity: a summary of the UK Walking the way to Health and the Green Gym initiatives. London: The Countryside Agency, 2002 (http, //www.whi.org.uk).

26 Parliamentary Office of Science and Technology. Postnote: health benefits of physical activity. London: Parliamentary Office of Science and Technology, 2001.

27 Department of Transport. Transport 2010: meeting the local transport challenge. London: Department of Transport, 2001. 